\title{
Addendum \\ Addendum: Kotál et al. Ixodes ricinus Salivary Serpin Iripin-8 Inhibits the Intrinsic Pathway of Coagulation and Complement. Int. J. Mol. Sci. 2021, 22, 9480
}

Jan Kotál ${ }^{1,2} \mathbb{D}$, Stéphanie G. I. Polderdijk ${ }^{3} \mathbb{D}$, Helena Langhansová ${ }^{1}$, Monika Ederová ${ }^{1}$, Larissa A. Martins ${ }^{2} \mathbb{D}$, Zuzana Beránková $^{1}$, Adéla Chlastáková ${ }^{1}\left(\mathbb{D}\right.$, Ondřej Hajdušek $^{4}$, Michail Kotsyfakis ${ }^{1,2} \mathbb{D}^{\mathbb{D}}$, James A. Huntington ${ }^{3}$ and Jindřich Chmelař $1, * \mathbb{D}$

check for

updates

Citation: Kotál, J.; Polderdijk, S.G.I.; Langhansová, H.; Ederová, M.;

Martins, L.A.; Beránková, Z.;

Chlastáková, A.; Hajdušek, O.;

Kotsyfakis, M.; Huntington, J.A.; et al. Addendum: Kotál et al. Ixodes ricinus Salivary Serpin Iripin-8 Inhibits the Intrinsic Pathway of Coagulation and Complement. Int. J. Mol. Sci. 2021, 22, 9480. Int. J. Mol. Sci. 2021, 22, 11271. https://doi.org/10.3390/ ijms222011271

Received: 18 September 2021 Accepted: 22 September 2021 Published: 19 October 2021

Publisher's Note: MDPI stays neutral with regard to jurisdictional claims in published maps and institutional affiliations.

Copyright: () 2021 by the authors Licensee MDPI, Basel, Switzerland. This article is an open access article distributed under the terms and conditions of the Creative Commons Attribution (CC BY) license (https:/ / creativecommons.org/licenses/by/ $4.0 /)$.
1 Department of Medical Biology, Faculty of Science, University of South Bohemia in České Budějovice, Branišovská 1760c, 37005 České Budějovice, Czech Republic; jan.kotal@nih.gov (J.K.); hlanghansova@prf.jcu.cz (H.L.); ederom01@prf.jcu.cz (M.E.); beranz02@prf.jcu.cz (Z.B.); chlasa00@prf.jcu.cz (A.C.); kotsyfakis@paru.cas.cz (M.K.)

2 Laboratory of Genomics and Proteomics of Disease Vectors, Institute of Parasitology, Biology Center CAS, Branišovská 1160/31, 37005 České Budějovice, Czech Republic; larissa.martins@nih.gov

3 Cambridge Institute for Medical Research, Department of Haematology, University of Cambridge, The Keith Peters Building, Hills Road, Cambridge CB2 0XY, UK; stephanie.polderdijk@cantab.net (S.G.I.P.); jah52@cam.ac.uk (J.A.H.)

4 Laboratory of Vector Immunology, Institute of Parasitology, Biology Center CAS, Branišovská 1160/31, 37005 České Budějovice, Czech Republic; hajdus@paru.cas.cz

* Correspondence: chmelar@prf.jcu.cz

The accession code will be added in Section 2.8. Structural Features of Iripin-8: The coordinates and structure factors of Iripin- 8 are deposited in the Protein Data Bank under accession code 7PMU.

This addendum does not cause any changes to the results or conclusions in the original published paper [1].

\section{Reference}

1. Kotál, J.; Polderdijk, S.G.I.; Langhansová, H.; Ederová, M.; Martins, L.A.; Beránková, Z.; Chlastáková, A.; Hajdušek, O.; Kotsyfakis, M.; Huntington, J.A.; et al. Ixodes ricinus Salivary Serpin Iripin-8 Inhibits the Intrinsic Pathway of Coagulation and Complement. Int. J. Mol. Sci. 2021, 22, 9480. [CrossRef] [PubMed] 